\title{
Pronominal address among Russian Germans in the Altai Krai - preliminary results of empirical data
}

\author{
Yves-Oliver Tauschwitz (Frankfurt/Oder)
}

\begin{abstract}
The German personal pronoun $I h r$ is the origin of an interesting difference in the address system of Russian Germans and Germans. Whilst the usage of this pronoun has shifted strongly in the last 100 years in Germany, it has been revealed that Russian Germans still use it in the same way as their predecessors. But since these observations date back more than ten years, the purpose of this study was to explore the current usage of personal pronouns among Russian Germans in the Altai Krai. For that purpose fourteen Russian Germans from the German National District and Barnaul were interviewed. This study combines quantitative and qualitative methods, as each respondent was presented a survey and went through a guided interview. As a result, two decision trees for the interviewed Mennonites on the one hand, and Catholics and Lutherans on the other hand, could be composed. The interviewed Russian Germans obviously still adhere to power semantics in the family, among friends and at work. While the Catholics and Lutherans were still employing Ihr, Mennonites used See in order to formally address one interlocutor. This study has also been able to identify Russian Germans' usage of the German dialect in the family and with friends.
\end{abstract}

\section{$1 \quad$ Introduction}

Today, there are still some communities in Russia where Russian Germans live. Invited by the Russian tsars Katharina II and Alexander I, their ancestors migrated to the Russian Empire in the $18^{\text {th }}$ and $19^{\text {th }}$ centuries. These first migrants colonized the European part of modern-day Russia and the north-western Black Sea region. It is noteworthy that among them were Lutherans, Catholics and Mennonites who spoke different dialects of German (see Hertel 1992: 22-23, and Rosenberg 1997: 585). ${ }^{1}$ The following figure gives an overview of the migration of Germans to the Russian Empire in the $18^{\text {th }}$ and $19^{\text {th }}$ centuries:

\footnotetext{
${ }^{1}$ At that time no standardized variety of German had been adopted throughout the German principalities.
} 


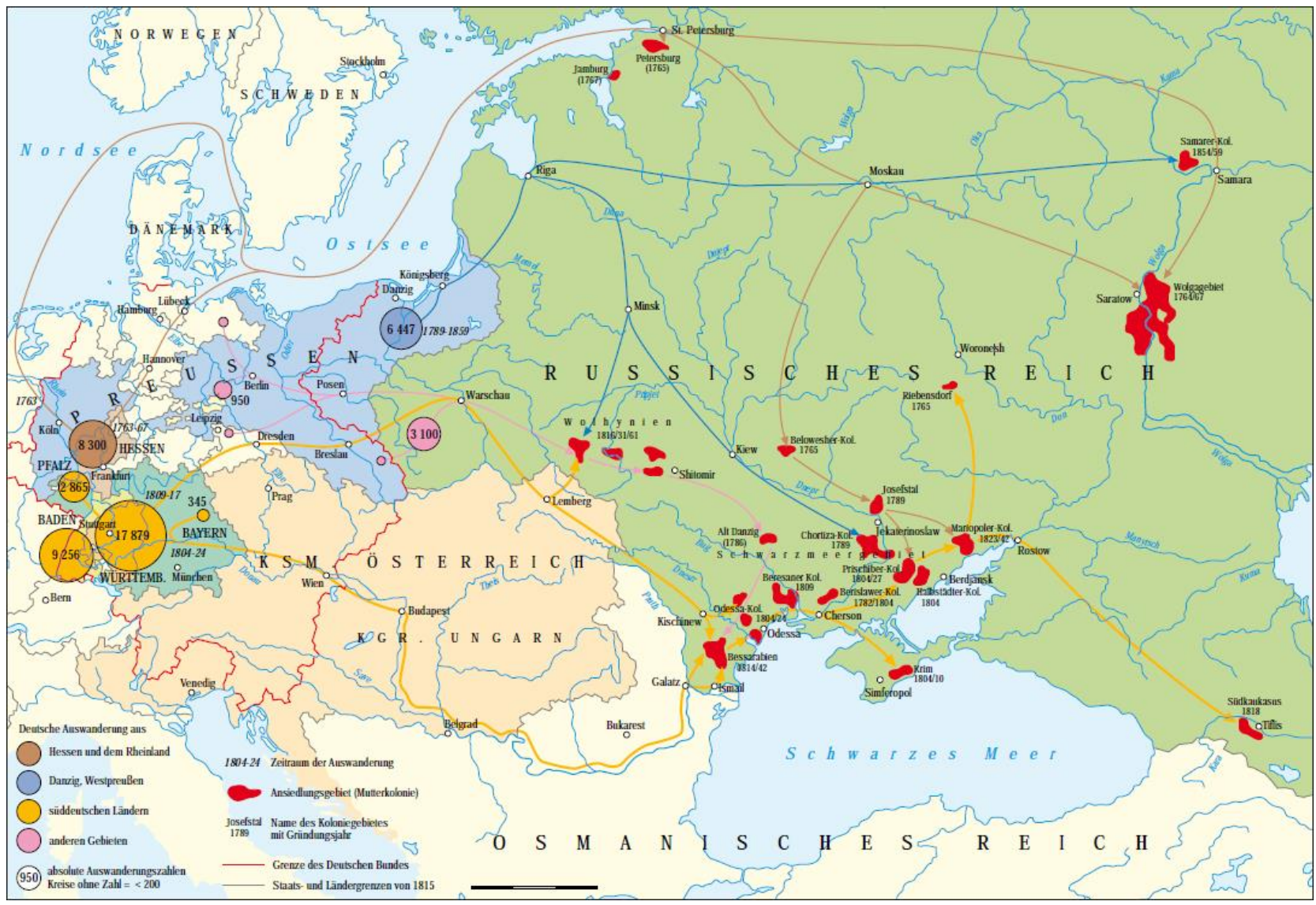

Figure 1: Migration of Germans to the Russian Empire in the 18th and 19th centuries (see Kompetenzzentrum für Integration Arnsberg 2005).

At the end of the $19^{\text {th }}$ century, some Russian Germans from these so-called mother colonies set out to found daughter colonies in Siberia and Central Asia (see Hertel 1992: 28-29, and Rosenberg 1997: 586-588). One area they settled was the German National Rayon, located in the Altai Krai:

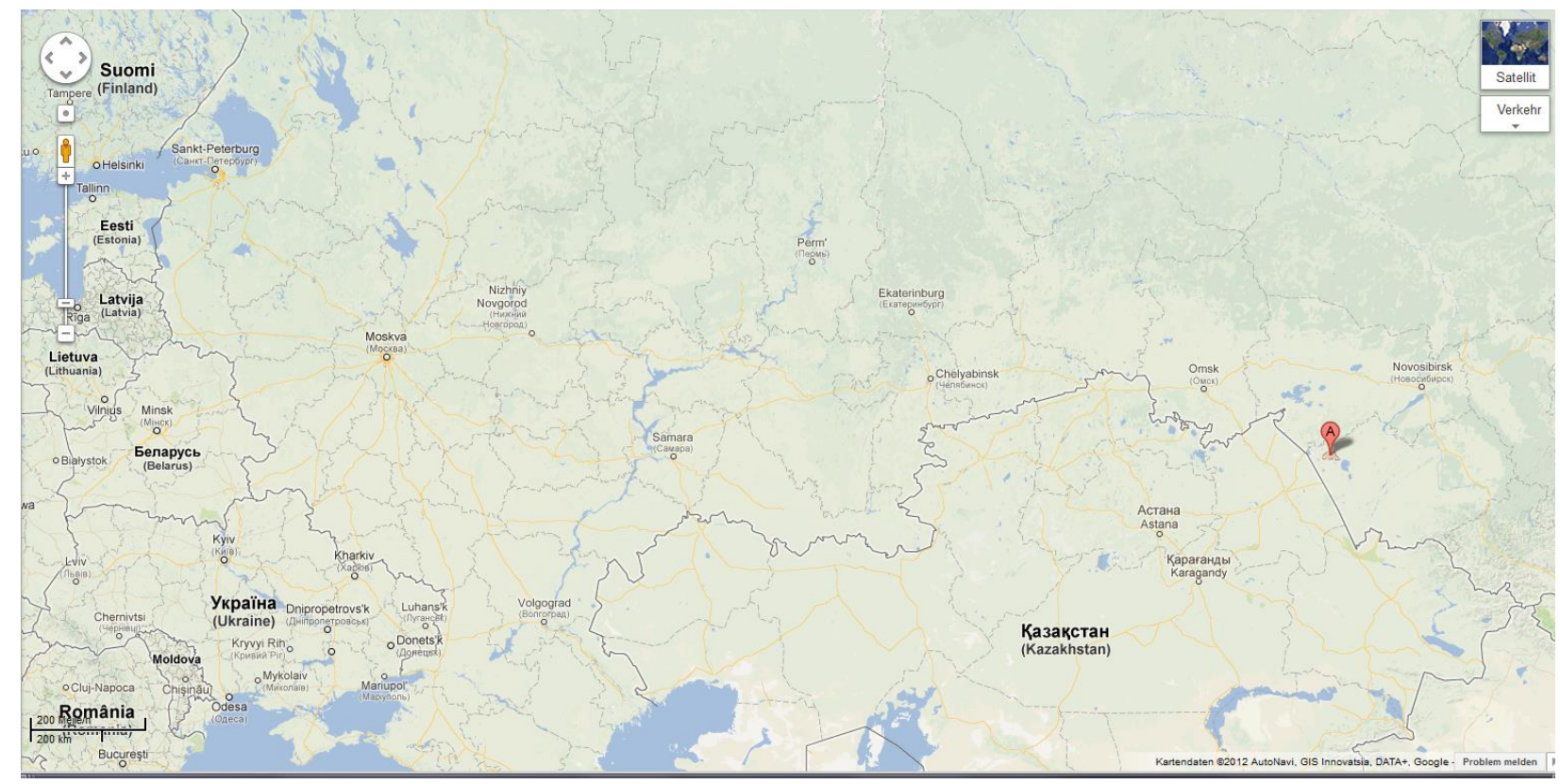

Figure 2: The German National Rayon in the South-East of Siberia (Source: googlemaps). 
A small number of ethnic Germans still inhabit different parts of the former Soviet Union, while many have emigrated to Germany. ${ }^{2}$ Some of them live in so-called speech islands. Speech islands can be defined as spatially confined and internally structured settlement areas of a linguistic minority within a majority that speaks another language (see Hutterer 1982: 178). ${ }^{3}$ Russian Germans have preserved modes of address that are no longer used in Germany. This might be the result of isolation from their forefathers' home country and/or the influence of the Russian language - their first or second language - on their German dialect. Due to language contact between Lutheran, Catholic and Mennonite settlers, "mixed, levelled or merged dialects" (Rosenberg 2006: 4) evolved. It is noteworthy that today, the terms Lutheran, Catholic and Mennonite do not necessarily reflect the religious affiliation of the Russian Germans; they rather refer to dialect varieties. As Russian Germans identify themselves as Lutherans, Catholics and Mennonites, this terminology is also employed in the scientific literature (see Rosenberg 1997, forthcoming). Catholics in the Altai Krai often use a linguistic variety that shows several features that are characteristic of West Upper German. While many Lutherans speak a West Central German idiom, numerous Mennonites employ an East Low German one (see id. 1997). The fact that Russian Germans still use the personal pronoun $\mathrm{Ihr}$ instead of Sie when formally addressing one or more interlocutors was last documented by studies that date back to the 1990s (see id. 1994). That raises the question whether this personal pronoun is still employed today, and whether its usage has an effect on the address etiquette among Russian Germans.

The current study aims to supplement the speech island research in Russia (see id. 1994, 2003, forthcoming or Damus 2010) by putting emphasis on the phenomenon of personal pronouns as a marker of "semantics of power and of solidarity". ${ }^{4}$ Personal pronouns belong to forms of address that refer to the interlocutors (see Braun 1988: 7-10). Address was established as a domain of sociolinguistics in the 1960s by Roger Brown, Albert Gilman and Marguerite Ford (see id.: 297; Brown/Gilman 1960; and Brown/Ford 1961).

To my knowledge, no experimental work has been done on the employment of personal pronouns among Russian Germans. Therefore, I decided to conduct explorative research (see Flick et al. 1991: 19-21) on pronominal address among Russian Germans in two areas in the Altai Krai. The qualitative interpretation of recorded interviews and questionnaires enabled me to find out in which domains the German dialect is still prevailing, and in which Russian already dominates. At the same time, I wanted to investigate whether the archaic $\mathrm{Ihr}$ also resulted in the conservation of the semantics of power that governed the German address system in the $18^{\text {th }}$ and $19^{\text {th }}$ centuries (see Brown/Gilman 1960: 173). ${ }^{5}$

\footnotetext{
2 Between 1991 and 2001 more than 500000 Ethnic Germans took the opportunity to become German citizens. In order to do so, they had (and still have) to meet certain conditions (see Bundesministerium des Innern 2010: 49-52).

3 Another example of a German speech island apart from the one that is presented in the current study is the region around Pelotas, Rio Grande do Sul, in southern Brazil. Currently I am involved in a DFG funded project that is coordinated by Peter Rosenberg, European University Viadrina. It aims at describing and explaining the degradation processes in case morphology in disappearing speech islands in the above mentioned region in Brazil and in the Altai Krai.

4 These terms were introduced by Roger Brown and Albert Gilman. They describe "semantics of power" as verbal or nonverbal behaviour that communicates differences in status between two or more interlocutors. In that sense, age or profession of those involved in a conversation are more important than friendly or familiar bonds between them. Brown and Gilman argue that the "semantics of power" governed the address systems of medieval Europe. Today, however, the semantics of solidarity prevail. That is, even though two interlocutors may be of different age or social position, they may become more intimate as they develop a friendship (see Brown/Gilman 1960: 173).

${ }^{5}$ For a detailed description of the development of the German address system see Simon 1997: 268-272.
} 
It is remarkable that the formal $I h r$ apparently fulfils the same function as the Russian personal pronoun $V y$. As the Russian Vy and the French vous, Ihr can be used to formally address one or more interlocutors. And it may be used as an informal address to more than one interlocutor. The grammatical proximity of the Russian $V y$ and the German Ihr offers a possible explanation of how the latter has been retained until today.

The asymmetrical usage of personal pronouns is characteristic of the "semantics of power", as it puts emphasis on the difference in status that results from asymmetries in age or profession. That is the case when a mother speaks to her daughter using the informal $d u$, but expects to be addressed with the formal Sie. The same employment of personal pronouns would be expected in the communication between an older friend and a younger one. The "semantics of power" do not occur often in $21^{\text {st }}$ century Germany and Russia, however. ${ }^{6}$ Today, "semantics of solidarity" prevail, where the paramount factor determining the formality of a situation is the social distance between the interlocutors involved. Therefore, in the intimate family domain, mother and daughter would mutually address each other with the informal $d u$. Also, when acquaintances develop into friendships, a mutual exchange of formal Sie usually gives way to a symmetrical $d u$ (for the change from formal to informal pronouns of address see Hickey 2003: 401). As power is often no longer the crucial factor, the interlocutors are able to redefine their relationship, even if there are hierarchical differences between them (see Brown/Gilman 1960: 173; and Brown/Levinson 1987: 79).

\section{Approach}

This study ${ }^{7}$ puts an emphasis on quantitative data that was collected with the help of a questionnaire. The questionnaire was filled in by the interviewer himself while he was posing the questions to the interlocutors. This process was recorded. The interviews were conducted mostly in German, and the informants' answers were in German as well.

The basis for the analysis is the quantitative evaluation of the questionnaire. Its results are semantically enriched and validated with the help of the audio-recording, and by taking into consideration the answers of non-professionals ${ }^{8}$ given during a guided interview. Generally speaking, I tried to give a coherent picture of the pronominal address among Russian Germans in the Altai Krai by combining qualitative and quantitative data (see Flick et al. 1991: 432, who call the combination of different methods "triangulation").

\section{$3 \quad$ Research design}

\subsection{Questionnaire}

I devised a questionnaire 9 that aimed to reveal in which situations the German personal pronouns $I h r, d u$ and Sie are employed by the interviewees. The informants were confronted with 20 situations. In each situation, one person asks the other whether he or she would like to have some more tea. The situations covered the following domains: family, friends, shop/restaurant, work, church, school, and on the street. The last domain was defined as any conversation with strangers. The interlocutors were asked to decide whether the approached person in each situation had to be addressed with $I h r, d u$ or Sie. The final part of the

\footnotetext{
6 Two prominent examples of semantics of power in today's Germany are conversation between teachers and pupils at school (see Ehlers 2009), and conversation between adults and children.

${ }^{7}$ See Tauschwitz (2011) for the detailed description of the research project.

${ }^{8}$ Flick calls this the narrative truth that can be defined as a plausible explanation or a good story (cf. Flick et al. 1991: 432) that the interlocutors give themselves.

${ }^{9}$ For the design of the questionnaire see Irreguläre Morphologie (2009).
} 
questionnaire was made up of socio-demographic information on the interviewees. Thus, my interpretations were supplemented by information like gender, age, education, or profession.

\subsection{Guided interview}

The questionnaire was framed by a set of standardized questions (see Atteslander 1993: 171) that were posed to all informants. Through an introductory interview, the interlocutors could familiarize themselves with the interviewer. At the same time, the informants were given the opportunity to reflect on their acquisition of German, on how they use it in everyday life and on their attitudes towards Germany. Just before the questionnaire, they were asked whether their dialect is at risk of extinction, and whether they are going to actively pass their linguistic heritage on to the next generations. The second interview that followed the questionnaire was supposed to supplement and validate the answers given before.

\subsection{Subjects}

The corpus of the study contains questionnaires and interviews with 14 Russian Germans. In total, I interviewed nine female and five male informants in the three villages of Halbstadt, Kusak and Schumanowka in the German National Rayon and in the city of Barnaul:

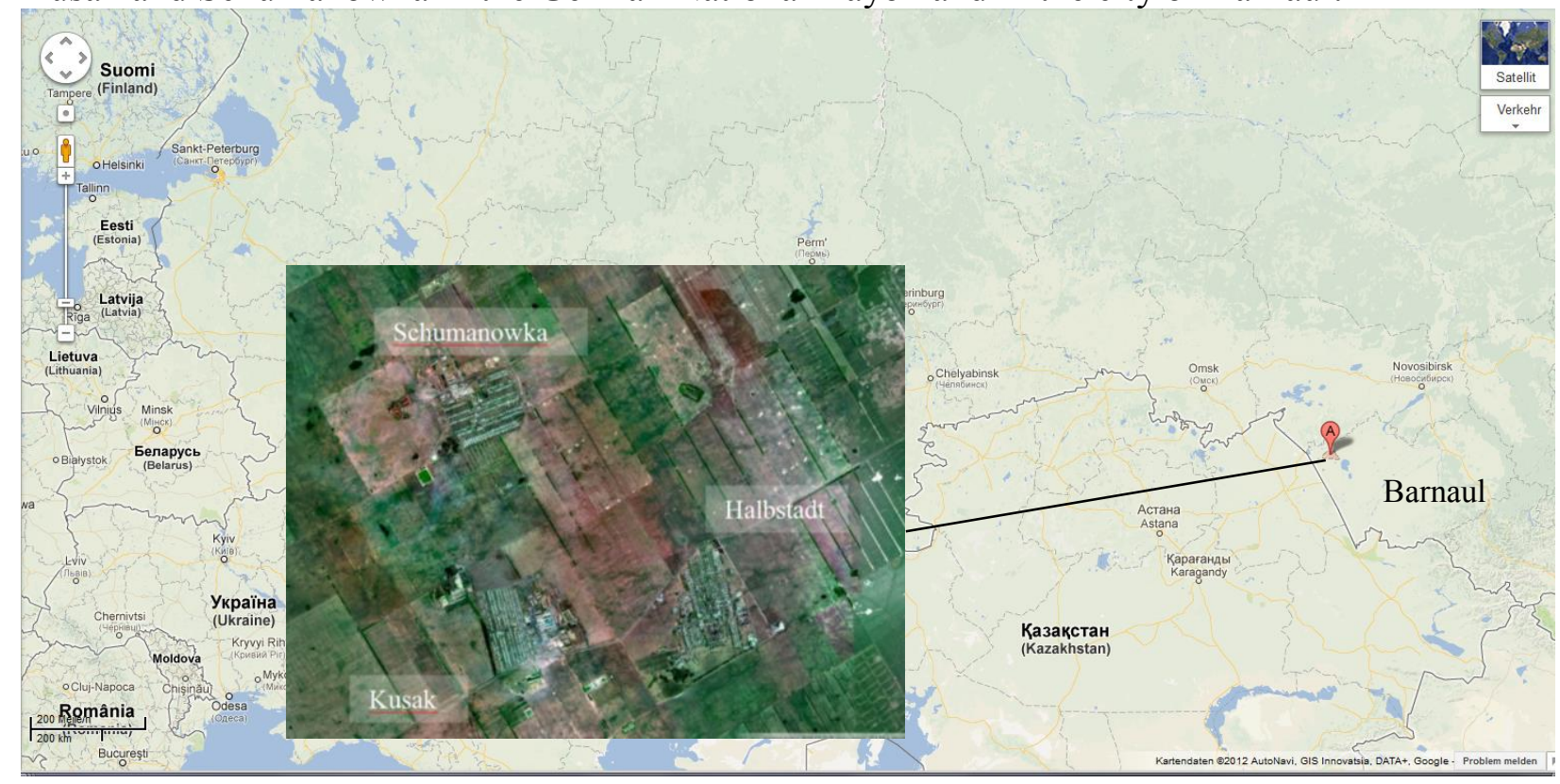

Figure 3: The German National Rayon in the South-East of Siberia (googlemaps.com and yandex.ru).

The majority of the interlocutors were between 70 and 90 years old, five of them spoke a Mennonite dialect variety, seven used a Catholic or Lutheran dialect variety. The two youngest informants described themselves as speakers of Standard German.

\section{$4 \quad$ Results}

My study suggests that Russian Germans still use their German dialects in the family and among friends, whereas Russian dominates the other spheres of their lives. This interpretation is based on the claims of interviewees that the Russian language prevails in the domains restaurant/shop, work ${ }^{10}$, school and church. I interpreted their choice of German personal pronouns in those four domains as a translation from Russian. In the questionnaire the domain

10 Since the informants are familiar with the Selsowet, the local administration (selsky sovet is literally translated as "village council"), the work domain was situated here. 
on the street is represented by the interaction between the interviewer and the informant in situations 1.19 and 1.20 .

Figure 4 gives an overview of the informants' answers in the first part of the questionnaire. $I h r, d u$ and Sie denote the personal pronouns chosen by the interlocutors in the given situation. The numbers in brackets refer to the original order of the questions. In the domains work and school, some informants argued that the choice of personal pronoun would depend on the age of the interlocutors involved in the respective situation. In the following table these cases were categorized as age.

\section{Questionnaire Part I - Overview (all informants: $\mathrm{n}=14$ )}

Please envisage the following situations, where one person asks another one, whether she or he wants some more Tea. Please select the answers that suit the particular situation. (In case of doubt, please think about how you would act if you were dealing with a German)
O Do you [Ihr] want more tea? $\mathrm{O}$ Do you [Du] want more tea? O Do you [Sie] want more tea?

Informants' answers



Figure 4: Graphical illustration of all the informants' answers in the first part of the questionnaire. ${ }^{11}$

The German dialects appear to be a relict of the first German settlers to the Russian Empire in the $18^{\text {th }}$ and $19^{\text {th }}$ centuries. The existence of $\mathrm{Ihr}$ (archaic in Standard German ${ }^{12}$ ) and the

\footnotetext{
${ }^{11}$ The original questionnaire is in German. It has been translated into English for this article. The questions were also asked in a different order, but for the purpose of clearness they were grouped according to the explored domains.
} 
"semantics of power" that to some extent still govern the address behaviour of Russian Germans bear witness to this claim. The paramount importance of status could be seen in the address of family members and friends, as older interlocutors expect to be addressed with a formal pronoun of address, but respond asymmetrically with an informal one. Furthermore, the "semantics of power" also appear to influence domains that are dominated by Russian language use, where among Russians the semantics of solidarity prevail. At work, a female employee is expected to use the formal personal pronoun when speaking to her male superior. She, in turn, is addressed by him with the informal personal pronoun. Even strangers are addressed according to their presumed age; if they appear to be 10 or more years younger than the speaker, they can be addressed in an informal way. One can conclude from the informants' answers that at school, "semantics of power" still appear to be dominant both among Russian Germans and Russians. Teachers are respectfully addressed by their pupils with a formal term of address, whereas they non-reciprocally respond with an informal term of address. At church, however, Russian Germans seem to have assimilated to the Russian address etiquette. Here, "semantics of solidarity" are predominant, as clergyman and believer reciprocally address each other with a formal pronoun of address. It is noteworthy that this shows how far the assimilation of the Russian Germans has already progressed, since the church traditionally is a sacrosanct domain of Standard German. ${ }^{13}$

In the course of the analysis it became apparent that the address behaviour of Mennonites is different from that of the Lutherans and Catholics. The Lutherans and Catholics usually employed the personal pronoun $I h r$, as was expected previously. The majority of Mennonites, however, chose the personal pronoun Sie. These tendencies are shown in the following figure ${ }^{14}$ :

\footnotetext{
12 As mentioned above, $I h r$ is used to formally address one or more interlocutors, or to address more than one interlocutor informally. This study focused on the use of the $I h r$ as a means of addressing one interlocutor formally only. It could be expected that Russian Germans also employ the $I h r$ for the other two functions.

13 This interpretation relies on the information gathered from the interviews. It is possible that during prayer and for singing German is still used, but, most likely, sermons are read in Russian. A high level of assimilation is also consistent with my own observations and the claims of some of my informants that even their adult offspring would rather speak Russian if their spouses were Russians, and that their grandchildren were brought up with Russian only. Following the classification of language endangerment by Michael Krauss, the German dialect varieties spoken by Russian Germans thus appear to be critically endangered (see Krauss 2007).

14 Here, only the answers of the twelve informants who affiliated themselves with one of the three dialect varieties are illustrated. Also, the situations are numbered and grouped according to the domains analyzed. In order to relate the numbers to specific situations see figure 4. As in figure 4, answers that argued that the age of the interlocutors would have to be taken into account were categorized as age.
} 


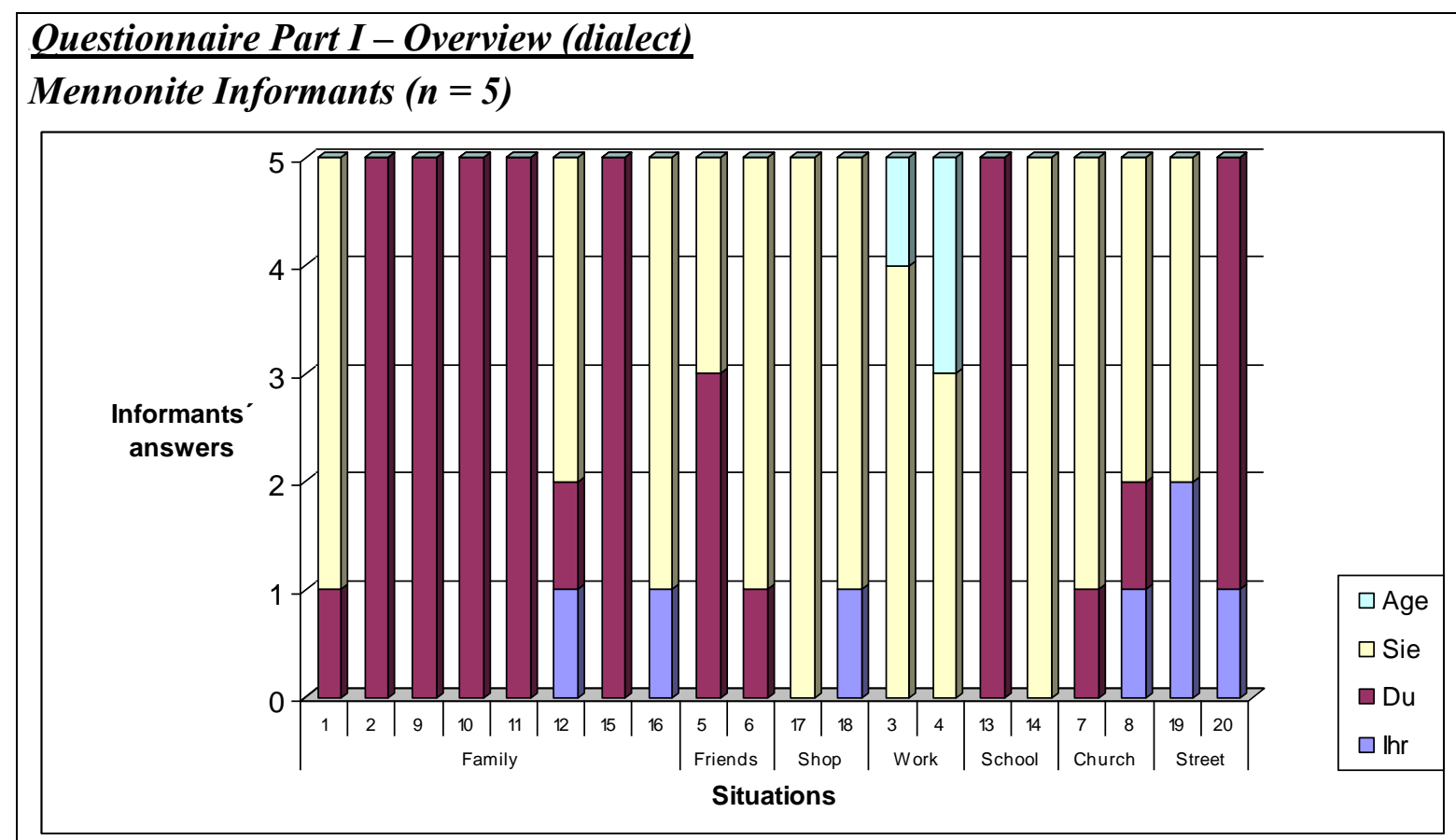

Catholic and Lutheran Informants $(n=7)$

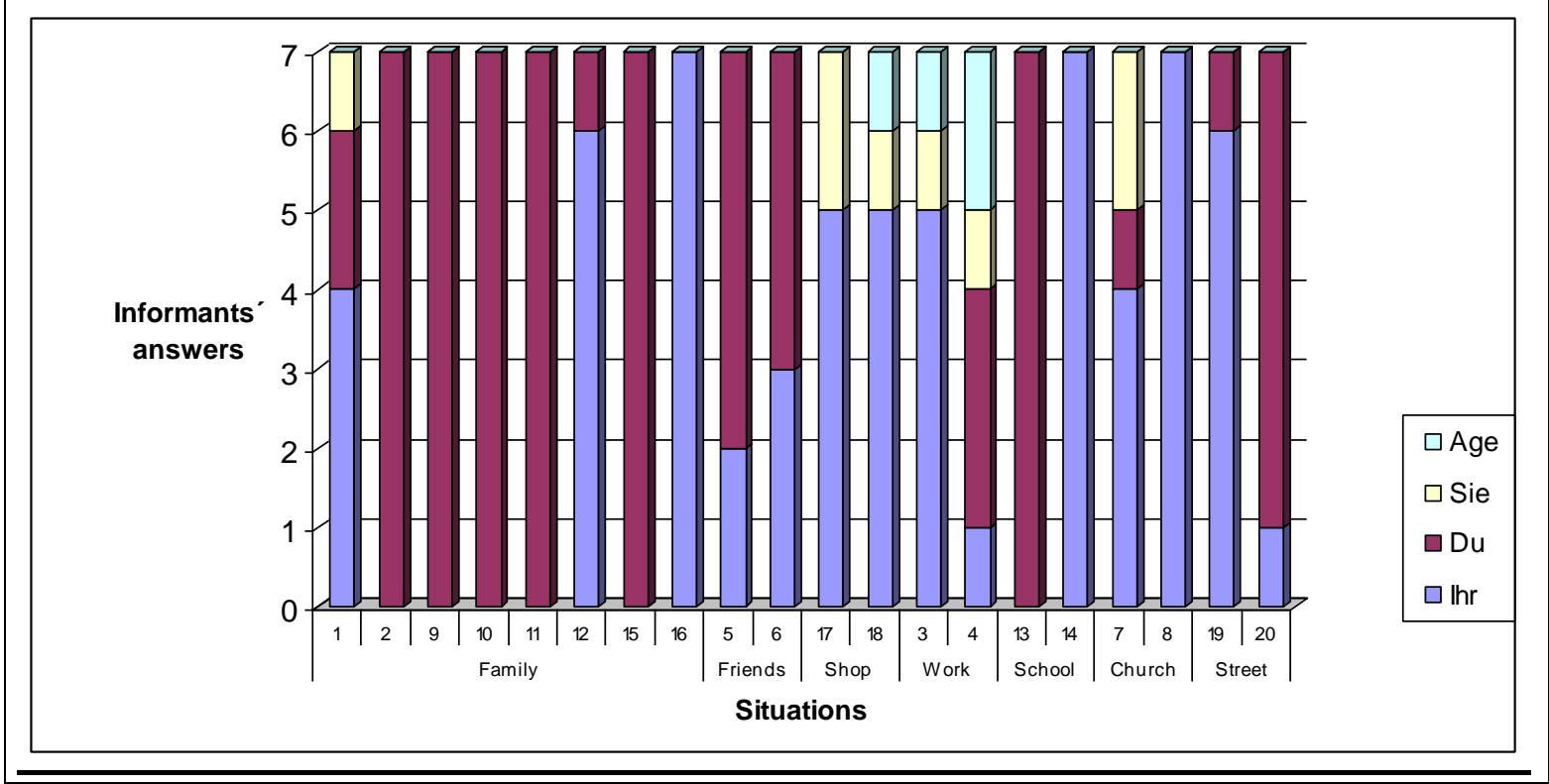

Figure 5: Graphical illustration of the informants' answers in the first part of the questionnaire in relation to their dialect variety.

The audio recording of the answers given in the questionnaire shed light on the fact that this Sie was pronounced as Sey [See] by most of the Mennonite informants. A similar pronoun, Se $[\mathrm{S} \varepsilon]$, is also mentioned in Wolfgang Lindow's grammar of Low German (see Lindow et al. 1998: 156).

In order to illustrate the results of the study, I tried to summarize them with the help of address diagrams. Address diagrams were introduced by Susan Ervin Tripp, and applied to German by Klaus Vorderwülbecke (see Vorderwülbecke 1976 and Ervin-Tripp 1972). They illustrate the interdependence of various address-relevant variables in a mathematical decision tree. In my study, the variables were Person known, In German, 10 years older, Family member, Spouse, Sibling, Friend, Colleague, Higher Status, and Clergyman. Since the 
address behaviour of Mennonites differs from that of Catholics and Lutherans, I designed two address diagrams for a 70-year old prototypical representative of both groups. The output of several personal pronouns, as well as dashed lines, indicate that the data suggested several possible alternatives. It should be noted that the diagrams are oversimplified and mirror my interpretation of the collected data. This holds especially true for the variables Colleague and Clergyman, as I interpreted the informants' choice of a German personal pronoun as a translation from the Russian one (see above). That is why, in these cases, a Russian personal pronoun that had apparently been translated into German by the informants can be found on the right side of the figures. Apart from the situations analyzed in this study, no other variables and domains were implemented in the address diagrams. Thus, the address of strangers in Russian was not included in the diagrams.

The following figure summarizes the pronominal address behaviour of a prototypical 70 -year old Mennonite:

Address diagram of a 70-year old Mennonite in the Altai Krai

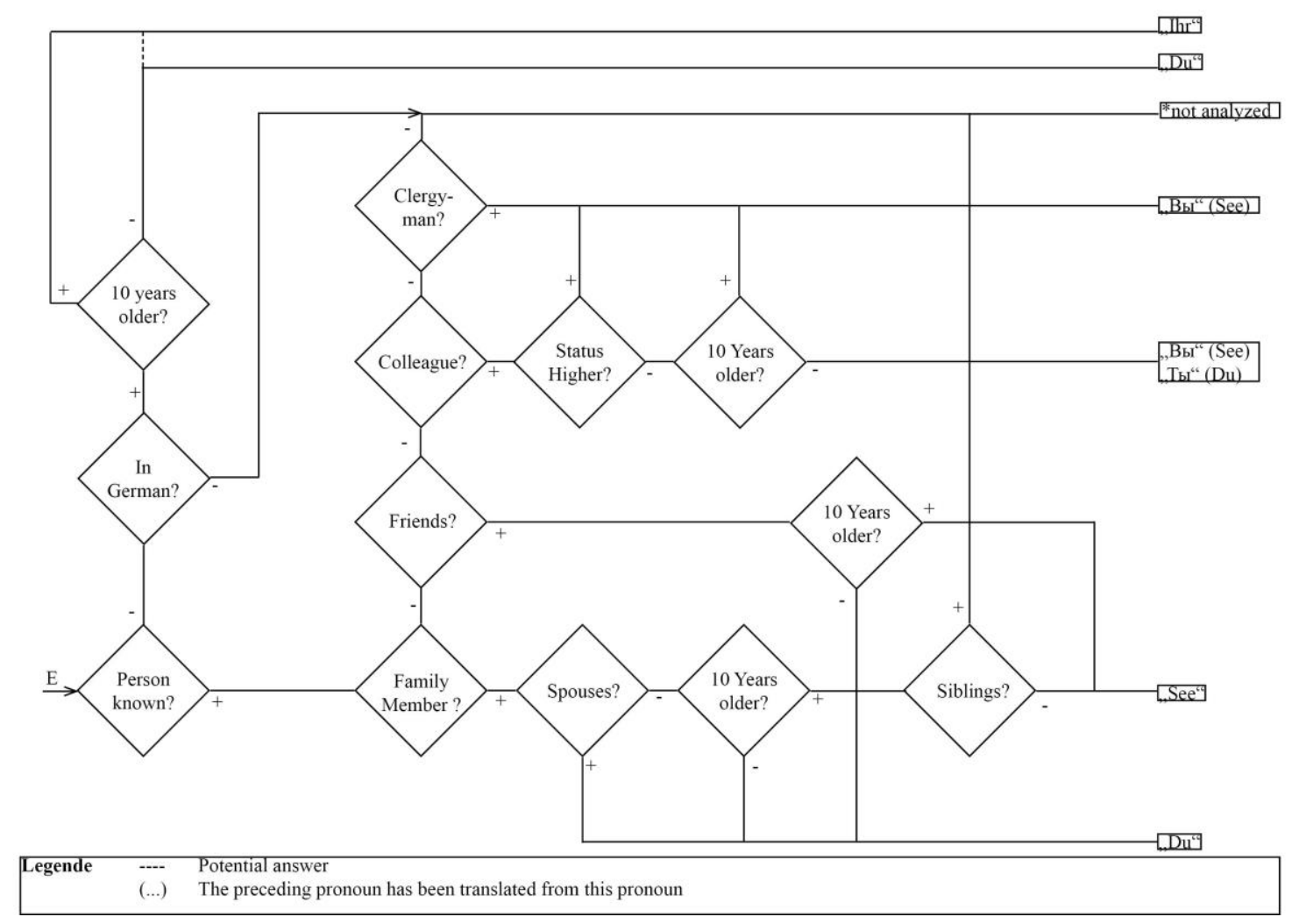

Figure 6: Address diagram of a 70-year old Mennonite in the Altai Krai. ${ }^{15}$

15 My data suggests that Mennonites usually use Sey. When addressing strangers, however, the majority of Mennonites chose $I h r$ instead of Sey. This divergent behaviour could be a point of departure for future research. 
The Mennonite address behaviour differs from the Lutheran and Catholic one, as can be seen in the following figure:

Address diagram of a 70-year old Lutheran or Catholic in the Altai Krai

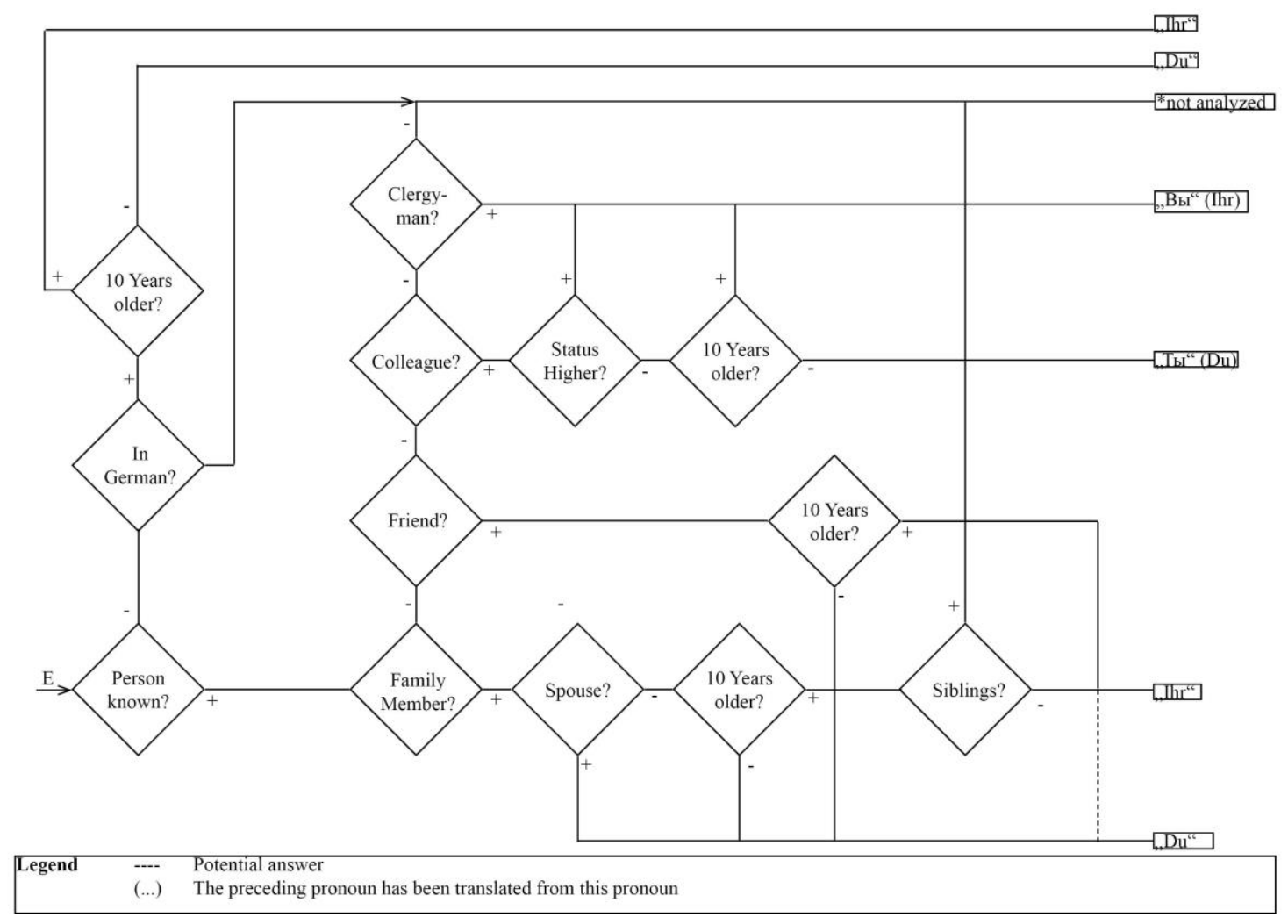

Figure 7: Address diagram of a 70-year old Lutheran or Catholic in the Altai Krai.

There were some limitations to the research design, however. Only a limited number of informants could be interviewed, and their selection depended on local guides. Four interlocutors are younger than the rest, but this did not have a significant impact on the results since their answers were comparable to those of the older informants. Apart from that, I did not fully implement all the qualitative material that I had gathered. Rather, the qualitative data was selected in order to support the quantitative data. Regarding the questionnaire, I focused only on the German address behaviour, and did not systematically ask the informants whether they would prefer German or Russian in the respective domains. In the current study, I relied on qualitative statements of the informants. Finally, the address behaviour of Russian Germans was oversimplified and homogenised in the address diagrams.

\section{Discussion and conclusion}

This study has shown that the German dialect varieties are still used within the family and among friends. These results are consistent with the outcome of Peter Rosenberg's study conducted in 1991 and 1992. The majority of the Russian Germans employed the German language for communication with spouses, parents and friends (see Rosenberg 1994: 289291). The current study also confirmed the initial assumption that the "semantics of power" are still applied when communicating with family members and friends. Furthermore, my data shows that, nowadays, Russian Germans are using Russian in the public domains work, school and church. This could be explained by the diglossic ${ }^{16}$ language setting. Due to the

16 According to Charles Ferguson (1959: 336), "diglossia is a relatively stable language situation in which, in addition to the primary dialects of the language [...], there is a very divergent, highly codified [...] superposed 
deportations after 1941 (see Winter-Heider 2009: 36), and due to the merging of villages in the 1970s and 1980s, Mennonites where mixed up with Catholics and Lutherans as well as with Russians, which resulted in Russian becoming the superposed variety as opposed to the German dialects that were now used mostly at home and among peers. As a result of a rise in mixed marriages among Russian Germans, Russians and Ukrainians (see Rosenberg 1997: 600-602, and Rosenberg 2003: 203), it is to be expected that Russian sooner or later would dominate over the German dialects, also within the family. Russian is already dominant in all public spheres. This marks a change with respect to the aforementioned study, where some Russian Germans had still used German at work.

Of paramount importance is the question whether the addressed persons are fluent in the same dialect as the speaker. Catholics and Lutherans, in particular, have difficulties in understanding Mennonites. All three groups, including the Lutherans and Catholics, would use their dialect amongst themselves. Communication between Mennonites and the other two groups (as well as the Russians), however, would be in Russian (see Rosenberg 1994: 293 294). In order to formally address somebody, Lutherans and Catholics employ Ihr. Mennonites use Sey for the same purpose. When addressing elder strangers, however, Mennonites as well as Lutherans and Catholics employ the formal Ihr.

To sum up, it should be emphasized that the analysis of Russian German speech islands allows one to observe many facets of modern sociolinguistics. I could conclude that among Lutherans, Catholics and Mennonites, German dialect varieties are still used in some domains. With regard to the employment of formal personal pronouns, I found that Catholics and Lutherans still use Ihr. Mennonites, however, employ Sey. In any case, the influence of the Russian language seems to be increasing.

Russian German speech islands can still be considered a linguistic laboratory (see Rosenberg 1997: 587). I conclude with a quote that is still valid today:

The new mixture of [linguistic] features that resulted from living closely together in the Russian German speech islands and that did not occur in that way in any dialect in Germany, was of great interest both to German and Russian dialectologists, since it allowed inferences on mechanisms of linguistic levelling that, for example, led to the emergence of the standard languages and colloquial varieties in Western and Central Europe. ${ }^{17}$

\section{References}

Atteslander, Peter (1993): Methoden der empirischen Sozialforschung. Berlin/New York: de Gruyter.

Braun, Friederike (1988): Terms of address. Problems of patterns and usage in various languages and cultures. Amsterdam/Berlin/New York: de Gruyter.

Brown, Penelope/Levinson, Stephen C. (1987): Politeness. Some universals in language usage. Cambridge et al.: Cambridge University Press.

Brown, Roger/Gilman, Albert (1960): "Die Pronomina der 'Macht' und 'Solidarität"'. In: Steger, Hugo (ed.): Anwendungsbereiche der Soziolinguistik. Darmstadt, Wissenschaftliche Buchgesellschaft: 163-198.

\footnotetext{
variety, $[\ldots]$ which is learned largely by formal education and is used for most written and formal spoken purposes but is not used by any sector of the community for ordinary conversation."

17 The passage was translated from German by the author of this article. The original quote reads: "Die durch das enge Zusammenleben in den rußlanddeutschen Sprachinseln hervorgerufene neue Mischung dieser [sprachlichen] Merkmale, die so in keinem binnendeutschen Dialekt auftrat, war für die Dialektologen in Russland wie in Deutschland gleichermaßen von größtem Interesse, ließ sie doch Rückschlüsse auf die Mechanismen des Sprachausgleichs zu, wie er zum Teil auch die Hochsprachen und Verkehrsvarianten in Westund Mitteleuropa erzeugt hatte." (Rosenberg 1997: 587)
} 
Brown, Roger/Ford, Marguerite (1961): "Address in American English." In: Hymes, Dell (ed.): Language in culture and society. New York et al., Harper \& Row: 234-244.

Bundesministerium des Innern (ed.) (2010): "Migrationsbericht 2010". http://www.bamf.de/SharedDocs/Anlagen/DE/Publikationen/Migrationsberichte/migration sbericht-2010.pdf, accessed March 8, 2013.

Damus, Sahra (2010): "Deutsche Sprachinseln in Russland - Spracherhalt oder Sprachwechsel?" In: Berichte und Forschungen. Jahrbuch des Bundesinstituts für Kultur und Geschichte der Deutschen im östlichen Europa 18: 143-154.

Ehlers, Klaas-Hinrich (2009): "Anrede in der Grundschule. Zur jüngeren Entwicklung des Anredeverhaltens in Deutschland." Zeitschrift für Germanistische Linguistik 37/2: 302325.

Ervin-Tripp, Susan (1972): "On sociolinguistic rules. Alternation and co-occurrence." In: Gumperz, John/Hymes, Dell (eds.): Directions in sociolinguistics. The ethnography of communication. New York et al., Holt, Rinehard \& Winston: 225-240.

Ferguson, Charles (1959): "Diglossia". Word 15: 325-340.

Flick, Uwe et al. (1991): Handbuch Qualitative Sozialforschung. München: Psychologie Verlagsunion.

Google Maps. https://maps.google.com/, accessed February 01, 2014.

Hertel, Otto (1992): "Das Manifest der Zarin." In: Warkentin, Johann (ed.): Russlanddeutsche. Woher? Wohin? Berlin, Aufbau: 21-39.

Hickey, Raymond (2003): "The German address system. Binary and scalar at once." In: Taavitsainen, Irma/Jucker, Andreas H. (eds.): Diachronic perspectives on address term systems. Amsterdam/Philadelphia, Benjamins: 401-425.

Hutterer, Claus J. (1982): "Sprachinselforschung als Prüfstand für dialektologische Arbeitsprinzipien". In: Besch, Werner et al. (eds.): Dialektologie. Ein Handbuch zur deutschen und allgemeinen Dialektforschung. Berlin/New York, de Gruyter: 178-189.

Irreguläre Morphologie (2009): Projektfragebogen des Projekts Regularität und Irregularität in der Kasusmorphologie deutscher Sprachinselvarietäten (Russland, Brasilien). Frankfurt/Oder: Europa-Universität Viadrina. Unpublished.

Kompetenzzentrum für Integration Arnsberg (ed.) (2005): "Karte-AuswanderungUrheberrecht-2-2005."

http://www.lum.nrw.de/Aufgaben/Integration/spaetaussiedler/historie/fotos/Karte-

Auswanderung-Urheberrecht-2-2005.pdf, accessed March 8, 2013.

Krauss, Michael (2007): "Classification and terminology for degrees of language endangerment". In: Brenzinger, Matthias (ed.): Language diversity endangered. Berlin/New York, de Gruyter: 1-8.

Lindow, Wolfgang et al. (1998): Niederdeutsche Grammatik. Leer: Schuster.

Rosenberg, Peter (1994): "Sprachgebrauchsstrukturen und Heterogenität in der Kommunikationsgemeinschaft bei den Deutschen in der GUS. Eine empirische Studie." In: König, Peter-Paul/Wiegers, Helmut (eds.): Satz-Text-Diskurs. Akten des 27. linguistischen Kolloquiums, Münster 1992. Tübingen, Max Niemeyer: 287-297.

Rosenberg, Peter (1997): "Die Sprache der Deutschen in Russland". In: Stricker, Gerd (ed.): Deutsche Geschichte im Osten Europas. Russland. Berlin, Siedler: 585-608.

Rosenberg, Peter (2003): "Comparative speech island research. Some results from studies in Russia and Brazil." In: Keel, William D./Mattheier, Klaus J. (eds.): Deutsche Sprachinseln weltweit. Interne und externe Perspektiven/German language varieties worldwide. Internal and external perspectives. Frankfurt a. M. et al., Lang: 199-238.

Rosenberg, Peter (2006): "Dialect convergence in German speech islands". In: Auer, Peter/Hinskens, Frans/Kerswill, Paul E. (eds.): Dialect change. Convergence and divergence in European languages. Cambridge: Cambridge University Press. 
Rosenberg, Peter (forthcoming): "Regularität und Irregularität in der Kasusmorphologie deutscher Sprachinselvarietäten (Russland, Brasilien)". In: Köpcke, Klaus-Michael/Bittner, Andreas (eds.): Regularität und Irregularität. Berlin: Akademie.

Simon, Horst J. (1997): "Die Diachronie der deutschen Anredepronomina aus Sicht der Universalienforschung". Sprachtypologie und Universalienforschung 50/3: 267-281.

Tauschwitz, Yves-Oliver (2011): Pronominale Anrede bei Russlanddeutschen in der Altairegion - eine qualitative und quantitative Studie. Europa-Universität Viadrina, Frankfurt/Oder. Unpublished.

Vorderwülbecke, Klaus (1976): "Anredeformen und Selbstbezeichnungen im Deutschen und Japanischen". In: Stickel, Gerhard (ed.): Deutsch-japanische Kontraste. Vorstudien zu einer kontrastiven Grammatik. Tübingen, Narr: 335-394.

Winter-Heider, Christiane E. (2009): Mutterland Wort. Sprache, Spracherwerb und Identität vor dem Hintergrund von Entwurzelung. Frankfurt/Main: Brandes \& Apsel.

Yandex. http://www.yandex.ru/, accessed February 01, 2014. 